\title{
Disposition Kinetics of Moxifloxacin in Calves Pretreated with Cow Urine Distillate
}

\author{
M. Meena*, A. Gaur, P. Sharma and N. Dinodia \\ Department of Veterinary Pharmacology and Toxicology, College of Veterinary and Animal \\ Sciences, RAJUVAS, Bikaner-334001 (Rajasthan), India \\ *Corresponding author
}

\section{Keywords}

Calves, Cow urine distillate,

Intramuscular, Moxifloxacin, Oral, Pharmacokinetics

Article Info

Accepted:

15 May 2019

Available Online:

10 June 2019

\section{A B S T R A C T}

Bio-enhancers such as piperine, curcumine, ginger and cow urine distillate are being seen as important adjuvant drugs to combat antimicrobial resistance and to increase efficiency of antimicrobial agents. Cow urine distillate is one of the important bio-enhancer easily available with farmer. The disposition kinetics was aimed to assess the pharmacokinetic alteration in profile of moxifloxacin, a third generation fluoroquinolone anti-microbial agent. Moxifloxacin was administered at the dose rate of $5 \mathrm{mg} \cdot \mathrm{kg}^{-1}$ body weight by intramuscular route in calves $(\mathrm{n}=5)$ pretreated with cow urine distillate at the dose of $20 \mathrm{ml}$ per day per animal orally for 7 days. The plasma concentration-time profile of moxifloxacin following intramuscular administration in the pretreated calves was best described by one-compartment open model. The absorption half-life $\left(t_{1 / 2 k a}\right)$, elimination half-life $\left(\mathrm{t}_{1 / \beta}\right)$, area under plasma drug concentration-time curve (AUC), area under first moment curve (AUMC), apparent volume of distribution $\left(\mathrm{Vd}_{\text {area }}\right)$, total body clearance $\left(\mathrm{Cl}_{\mathrm{B}}\right)$ and bioavailability $(\mathrm{F})$ of moxifloxacin were $0.33 \pm 0.04 \mathrm{~h}, 10.53 \pm 0.35 \mathrm{~h}, 44.70 \pm$ $3.71 \mu \mathrm{g} \cdot \mathrm{ml}^{-1} \cdot \mathrm{h}, 712.20 \pm 68.92 \mu \mathrm{g} \cdot \mathrm{ml}^{-1} \cdot \mathrm{h}^{2}, 1.75 \pm 0.17 \mathrm{~L} \cdot \mathrm{kg}^{-1}, 0.11 \pm 0.01 \mathrm{~L} \cdot \mathrm{kg}^{-1} \cdot \mathrm{h}^{-1}$ and $95.29 \pm 5.17 \%$ respectively. Cow urine distillate administration at the selected dose rate did not significantly alter the pharmacokinetic behavior of moxifloxacin administered intramuscularly in calves.

\section{Introduction}

Nowadays emergence of widespread drug resistance to the currently available antimicrobials is a matter of deep concern. Development of resistance to oral drug of choice fluoroquinolones, for urinary tract infections caused by Escherichia coli is very widespread, often sensitivity remains only for injectables. Infections caused by resistant microorganisms often fail to respond to the standard treatment, resulting in prolonged illness, higher health care expenditures and a greater risk of death (Randhawa and Sharma, 2015).

Co-administration of herbal drugs may result in unpredictable therapeutic outcome. Bioenhancers themselves do not possess inherent pharmacological activity of their own but when co-administered with Active Pharmaceutical Ingredients (API), enhance 
their bioavailability and efficacy. Bioenhancers play a crucial role in enhancing the bioavailability and bioefficacy of different classes of drugs, such as antihypertensives, antimicrobials, anticancer, antiviral, antitubercular and antifungal drugs at low doses. Several herbal bioenhancer compounds including piperine, quercetin, genistein, naringin, sinomenine, curcumin, glycyrrhizin and cow urine distillate have demonstrated capability to improve the pharmacokinetic parameter of several potent Active Pharmaceutical Ingredients (Ajazuddin et al., 2014).

In Vedas, the classical hindu literature, cow is considered the most valuable animal and is called Mother of all. Different products obtained from cow like urine, dung, milk, ghee and curd are used widely in number of Ayurvedic formulations (Shah et al., 2011).

Cow urine distillate is more effective as a bioenhancer than cow urine. It enhances the transport of antibiotics like rifampicin, tetracycline and ampicillin across the gut wall by two to seven folds. It also enhances the potency of taxol against MCF-7 cell lines.

It enhances the bioavailability of rifampicin by 80 fold in $0.05 \mu \mathrm{g} . \mathrm{ml}^{-1}$ concentration, ampicillin by 11.6 fold in $0.05 \mu \mathrm{g} \cdot \mathrm{ml}^{-1}$ concentration and clotrimazole by five fold in $0.88 \mu \mathrm{g} . \mathrm{ml}^{-1}$ concentration (U.S. Patent No. US 6,896,907 B2, 2005).

Cow urine also has antitoxic activity against the cadmium chloride toxicity and it can be used as a bioenhancer of zinc (Khan and Srivastava, 2005). The bioenhancing ability is by facilitating absorption of drugs across the cell membrane (Tatiraju et al., 2013; Mohanty et al., 2014). Cow urine distillate formulation has been granted US Patents $(6,410,059$ B1, 2002 and No. 6,896,907 B2, 2005) for its medicinal properties.
Moxifloxacin is a fourth generation fluoroquinolone with a methoxy group in the C-8 position and C-7 side chain. Moxifloxacin has in vitro activity similar to that of older fluoroquinolones against Gramnegative bacteria, but shows improved activity against Gram-positive cocci, aerobic, anaerobic intracellular bacteria, as well as atypical organisms, such as Mycoplasma and Chlamydia, compared with older fluoroquinolones (Fernández-Varón et al., 2006; Abd el-aty et al., 2008; Goudah, 2008; Pathaniya and Sharma, 2010).

Studies over interaction of antimicrobial agents with different bioenhancers have been done both, in vitro (Cai et al., 2007; Moghaddam et al., 2009; Ahmed et al., 2010), and in vivo such as in poultry (Singh $e t$ al., 2005; Patel et al., 2011), goats (Dama et al., 2008) and rabbits (Janakiraman and Manavalan, 2008; Okonta et al., 2008; Pavithra et al., 2009; Nduka et al., 2013). Several authors report cow urine distillate as a bioenhancer (Dhama et al., 2005; U.S. Patent No. US 7,235,262 B2, 2007; Jarald et al., 2008; Ahuja et al., 2012; Shekhar et al., 2012; Jhanwar and Gupta, 2014; Mohanty et al., 2014; Randhawa and Sharma, 2015; Sai et al., 2015; Dhakal et al., 2016; Shrinidhi et al., 2016).

There is no information available on the influence with the pretreatment of cow urine distillate on the pharmacokinetics of moxifloxacin in animals. Hence, the study was conducted to enrich the pharmacokinetic data of moxifloxacin in the concerned species and also to study any possible influence of cow urine distillate on the pharmacokinetics of moxifloxacin in calves.

\section{Materials and Methods}

For the present study, five apparently healthy female Sahiwal calves (A to E) aging 4-6 
months and weighing between 40-60 kg were taken from Livestock Research Station, Kodamdesar, RAJUVAS, Bikaner. Animals were kept and maintained in the respective farm in standard management conditions and were protected against endoparasites and ectoparasites. The animals had free access to roughage and water and were given standard ration. The experimental protocol and use of animals for conducting the present study had approval of Animal Ethics committee (IAEC).

The calves were pretreated with cow urine distillate (Gavyamrita Gau mutra ark, Pathmeda, Sanchore, Distt. Jalore, Rajasthan, India) at the dose rate of $20 \mathrm{ml}$ per day for seven days orally and after that, Moxifloxacin hydrochloride (inj. Mofoi ${ }^{\mathrm{TM}} 10$ per cent w/v; Bovian Health care Pvt. Ltd., Secunderabad, Telangana, India) was administered intramuscularly at the dose rate of $5 \mathrm{mg} \cdot \mathrm{kg}^{-1}$ body weight in the lower third region of the neck.

Blood samples (4-6 ml) were collected in test tubes containing EDTA as anticoagulant by venepuncture of jugular vein, immediately before administration of moxifloxacin $(0 \mathrm{~h})$ and at $0.04,0.08,0.17,0.25,0.5,0.75,1.0$, $1.5,2,4,6,8,10,12,24,36$ and $48 \mathrm{~h}$ after administration of the drug. Blood samples were centrifuged at $3000 \mathrm{rpm}$ for $15 \mathrm{~min}$ to separate the plasma. The plasma samples were stored at $-20^{\circ} \mathrm{C}$ until assayed.

Concentration of moxifloxacin in plasma samples were determined by microbiological assay method using MTCC equivalent Escherichia coli MTCC 443 (Arret et al., 1971).

The plasma moxifloxacin concentration time profile of each animal (pretreated with cow urine distillate at the dose rate of $20 \mathrm{ml}$ per day for seven days orally) following intramuscular administration were used to determine the pharmacokinetic variables describing the absorption, distribution and elimination characteristics of moxifloxacin in calves. To determine the different disposition kinetic variables, plasma drug concentrationtime data were analysed by employing the compartmental (Baggot, 2001; Gibaldi and Perrier, 2007) pharmacokinetic models.

\section{Results and Discussion}

The moxifloxacin plasma concentration versus time data and its semi-logarithmic graph (Fig. 1) after intramuscular administration (pretreatment with cow urine distillate) could be best described by a one compartment open model. The mean $( \pm S E)$ plasma concentrations of moxifloxacin following $5 \mathrm{mg} \cdot \mathrm{kg}^{-1}$ intramuscular doses in calves pretreated with cow urine distillate has been shown in Table 1. Moxifloxacin was detected in plasma up to $36 \mathrm{hr}$ after intramuscular administration. The mean $( \pm S E)$ pharmacokinetic parameters are presented in Table 2.

In present study, $\mathrm{C}_{\max }$ of moxifloxacin was observed $3.01 \pm 0.26 \mu \mathrm{g} \cdot \mathrm{ml}^{-1}$ which was almost similar to that observed in calves given moxifloxacin alone $\left(3.05 \pm 0.25 \mu \mathrm{g} \cdot \mathrm{ml}^{-1}\right)$. Similarly no significant alteration in $\mathrm{C}_{\max }$ was reported when pefloxacin was given orally in rabbits pretreated with ginger extract (Nduka et al., 2013).

The time taken to achieve peak plasma concentration $\left(\mathrm{t}_{\max }\right)$ of moxifloxacin in cow urine distillate treated calves was $1.50 \pm 0.00$ $\mathrm{h}$ which was slightly lower than the same observed in calves given moxifloxacin alone $(1.70 \pm 0.12 \mathrm{~h})$, but the difference was not statistically significant. No significant difference in $t_{\max }$ was observed in rabbits when pefloxacin was administered alone or along with ginger extract (Nduka et al., 2013). 
The absorption half-life ( $\left.t_{1 / 2 k a}\right)$ of moxifloxacin after intramuscular administration in calves pretreated with cow urine distillate was found to be $0.33 \pm 0.04 \mathrm{~h}$, which is slightly lower to that observed when moxifloxacin is given alone $\left(\mathrm{t}_{1 / 2 \mathrm{ka}}\right.$ of $\left.0.45 \pm 0.08 \mathrm{~h}\right)$ suggesting pretreatment with cow urine distillate does not alter the absorption of moxifloxacin in calves. No significant alteration in $\mathrm{t}_{1 / 2 \mathrm{ka}}(0.35 \pm$ 0.07 to $0.45 \pm 0.08 \mathrm{~h}$ ) of oxytetracycline following pretreatment with Piper longum orally in hens was reported by Singh et al., 2005. No significant alteration was reported by Dama et al., 2008 in $t_{1 / 2 k a}$ values $(0.32 \pm$ 0.01 to $0.32 \pm 0.02 \mathrm{~h}$ ) of pefloxacin administered after pretreatment of trikatu orally in goats.

The elimination half-life $\left(t_{1} / 2 \beta\right)$ of moxifloxacin in the calves pretreated with cow urine distillate in the present study was found to be $10.53 \pm 0.35 \mathrm{~h}$ which is slightly higher to $t_{1 / 2 \beta}$ of $9.80 \pm 0.63 \mathrm{~h}$ observed in calves given moxifloxacin alone. However, significantly higher values of $t_{1 / 2 \beta}$ of pefloxacin was found in goats when it was pretreated with trikatu orally $(3.30 \pm 0.19 \mathrm{~h})$ in comparison to calves given pefloxacin alone $2.50 \pm 0.12 \mathrm{~h}$ (Dama et al., 2008). Similarly Singh et al., (2005) also reported higher $t_{1 / 2 \beta}$ in hens given oxytetracycline along with Piper longum $(6.37 \pm 0.44 \mathrm{~h})$ compared to hens given oxytetracycline alone $(4.93 \pm 0.42 \mathrm{~h})$. In the present study, the area under curve (AUC) of moxifloxacin when administered intramuscularly in the cow urine distillate pretreated calves was found to be $44.70 \pm$ $3.71 \mu \mathrm{g} \cdot \mathrm{ml}^{-1} . \mathrm{h}$ which is found slightly higher to the value of AUC observed in calves given moxifloxacin alone $\left(43.30 \pm 3.99 \mu \mathrm{g} \cdot \mathrm{ml}^{-1} . \mathrm{h}\right)$. The difference however, is non-significant. Nduka et al., (2013) reported significantly higher value of AUC in rabbits, administered with pefloxacin in ginger-treated rabbits $\left(36.84 \pm 4.84 \mu \mathrm{g} \cdot \mathrm{ml}^{-1} . \mathrm{h}\right)$ when compared with rabbits administered with pefloxacin alone $\left(21.37 \pm 7.44 \mu \mathrm{g} \cdot \mathrm{ml}^{-1} . \mathrm{h}\right)$. Singh et al., (2005) observed significantly higher values of AUC in hens given oxytetracycline in Piper longum treated hens $\left(6.42 \pm 0.37 \mu \mathrm{g} \cdot \mathrm{ml}^{-1} \cdot \mathrm{h}\right)$ in comparison to hens given oxytetracycline alone $\left(5.06 \pm 0.69 \mu \mathrm{g} \cdot \mathrm{ml}^{-1} . \mathrm{h}\right)$.

In the present study, the area under the moment curve (AUMC) value in the calves pretreated with cow urine distillate was observed $712.20 \pm 68.92 \mu \mathrm{g} \cdot \mathrm{ml}^{-1} \cdot \mathrm{h}^{2}$ which was found higher from the AUMC value $\left(650.05 \pm 85.19 \mu \mathrm{g} \cdot \mathrm{ml}^{-1} \cdot \mathrm{h}^{2}\right)$ observed in calves administered with moxifloxacin alone but no significant changes were found. In goats significantly higher value of AUMC $164.25 \pm 15.62 \mu \mathrm{g} \cdot \mathrm{ml}^{-1} \cdot \mathrm{h}^{2}$ was reported in trikatu treated goats in comparison to AUMC value of $121.10 \pm 4.07 \mu \mathrm{g} \cdot \mathrm{ml}^{-1} \cdot \mathrm{h}^{2}$ in goats given pefloxacin alone (Dama et al., 2008). Significantly higher value of AUMC has been reported in rabbits administered with norfloxacin alone $\left(13.40 \pm 1.62 \mu \mathrm{g} \cdot \mathrm{ml}^{-1} \cdot \mathrm{h}^{2}\right)$ and along with curcumin $\left(22.64 \pm 6.34 \mu \mathrm{g} \cdot \mathrm{ml}^{-}\right.$ $\left.{ }^{1} \cdot h^{2}\right)$ by Pavithra et al., (2009).

In the present study, mean residence time (MRT) in cow urine distillate pretreated calves was found to be $15.91 \pm 0.49 \mathrm{~h}$ which was slightly higher to the MRT value of 14.87 $\pm 0.91 \mathrm{~h}$ observed in calves administered with moxifloxacin alone but difference was not statistically significant. Pavithra et al., (2009) reported significant alteration in MRT value in rabbits $(5.01 \pm 0.19 \mathrm{~h}$ to $5.60 \pm 0.15 \mathrm{~h})$ given norfloxacin alone and along with curcumin. Significant alteration in MRT value has been reported by Dama et al., (2008) in goats administered with pefloxacin alone and in goats pretreated with trikatu with the corresponding values of $4.47 \pm 0.16 \mathrm{~h}$ and $5.27 \pm 0.27$ h, respectively. Singh et al., 2005 reported significant difference in the value of MRT in hens given oxytetracycline alone $(7.98 \pm 0.74 \mathrm{~h})$ and pretreatment with Piper longum $(9.77 \pm 0.64 \mathrm{~h})$. 
Table.1 Plasma concentrations of moxifloxacin $\left(\mu \mathrm{g} . \mathrm{ml}^{-1}\right)$ at different time intervals following its single intramuscular administration at the dose rate of $5 \mathrm{mg} \cdot \mathrm{kg}^{-1}$ body weight in calves pretreated with cow urine distillate orally (at the dose rate of $20 \mathrm{ml}$ per day for 7 days)

\begin{tabular}{|c|c|c|c|c|c|c|}
\hline \multirow{2}{*}{ Time(h) } & \multicolumn{7}{|c|}{ Animal Number } & \multirow{2}{*}{ Mean \pm S.E. } \\
\cline { 2 - 5 } & $\mathbf{A}$ & $\mathbf{B}$ & $\mathbf{C}$ & $\mathbf{D}$ & $\mathbf{E}$ & \\
\hline $\mathbf{0 . 0 4}$ & 0.40 & 0.20 & 0.50 & 0.20 & 0.48 & $0.36 \pm 0.06$ \\
\hline $\mathbf{0 . 0 8}$ & 0.65 & 0.50 & 0.75 & 0.25 & 0.80 & $0.59 \pm 0.09$ \\
\hline $\mathbf{0 . 1 7}$ & 1.00 & 0.55 & 1.02 & 0.30 & 1.00 & $0.77 \pm 0.14$ \\
\hline $\mathbf{0 . 2 5}$ & 1.30 & 0.66 & 1.25 & 0.74 & 1.50 & $1.09 \pm 0.16$ \\
\hline $\mathbf{0 . 5 0}$ & 1.65 & 0.88 & 1.60 & 1.25 & 2.00 & $1.48 \pm 0.19$ \\
\hline $\mathbf{0 . 7 5}$ & 1.99 & 1.30 & 1.90 & 1.66 & 2.25 & $1.82 \pm 0.16$ \\
\hline $\mathbf{1 . 0 0}$ & 2.50 & 1.50 & 2.40 & 2.50 & 2.80 & $2.34 \pm 0.22$ \\
\hline $\mathbf{1 . 5 0}$ & 2.74 & 2.20 & 3.00 & 3.50 & 3.60 & $3.01 \pm 0.25$ \\
\hline $\mathbf{2 . 0 0}$ & 2.65 & 2.00 & 2.90 & 3.34 & 3.20 & $2.82 \pm 0.23$ \\
\hline $\mathbf{4 . 0 0}$ & 2.32 & 1.80 & 2.74 & 2.60 & 2.75 & $2.44 \pm 0.17$ \\
\hline $\mathbf{6 . 0 0}$ & 2.02 & 1.44 & 2.25 & 2.10 & 2.44 & $2.05 \pm 0.16$ \\
\hline $\mathbf{8 . 0 0}$ & 1.64 & 1.30 & 2.00 & 1.80 & 2.20 & $1.79 \pm 0.15$ \\
\hline $\mathbf{1 0 . 0 0}$ & 1.38 & 1.14 & 1.80 & 1.52 & 1.80 & $1.53 \pm 0.12$ \\
\hline $\mathbf{1 2 . 0 0}$ & 1.04 & 1.00 & 1.50 & 1.20 & 1.55 & $1.26 \pm 0.11$ \\
\hline $\mathbf{2 4 . 0 0}$ & 0.55 & 0.52 & 0.62 & 0.60 & 0.90 & $0.64 \pm 0.06$ \\
\hline $\mathbf{3 6 . 0 0}$ & 0.25 & 0.25 & 0.30 & 0.30 & 0.40 & $0.30 \pm 0.02$ \\
\hline
\end{tabular}

Table.2 Pharmacokinetic determinants of moxifloxacin in calves following a single intramuscular dose at the rate of $5 \mathrm{mg} \cdot \mathrm{kg}^{-1}$ body weight in calves pretreated with cow urine distillate orally (at the dose rate of $20 \mathrm{ml}$ per day for 7 days)

\begin{tabular}{|c|c|c|c|c|c|c|c|}
\hline \multirow[t]{2}{*}{ Parameter } & \multirow[t]{2}{*}{ Unit } & \multicolumn{5}{|c|}{ Animal Number } & \multirow[t]{2}{*}{ Mean \pm S.E. } \\
\hline & & $\mathbf{A}$ & B & C & D & $\mathbf{E}$ & \\
\hline $\mathbf{A}^{\prime}$ & $\mu \mathrm{g} \cdot \mathrm{ml}^{-1}$ & 5.6741 & 2.7834 & 4.1788 & 5.9605 & 5.0791 & $4.73 \pm 0.57$ \\
\hline $\mathbf{K}_{\mathbf{a}}$ & $\mathrm{h}^{-1}$ & 3.2265 & 1.6727 & 1.7133 & 2.2055 & 2.2990 & $2.22 \pm 0.28$ \\
\hline $\mathbf{t}_{1 / \mathrm{Ka}}$ & $\mathrm{h}$ & 0.2148 & 0.4143 & 0.4045 & 0.3142 & 0.3014 & $0.33 \pm 0.04$ \\
\hline B & $\mu \mathrm{g} \cdot \mathrm{ml}^{-1}$ & 2.9132 & 2.2062 & 3.4203 & 3.3608 & 3.5552 & $3.09 \pm 0.25$ \\
\hline B & $\mathrm{h}^{-1}$ & 0.0698 & 0.0612 & 0.0684 & 0.0703 & 0.0606 & $0.07 \pm 0.002$ \\
\hline$t_{1 / 2 \beta}$ & $\mathrm{h}$ & 9.9284 & 11.3235 & 10.1316 & 9.8577 & 11.4356 & $10.53 \pm 0.35$ \\
\hline $\mathrm{C}_{\max (\mathrm{obs})}$ & $\mu \mathrm{g} \cdot \mathrm{ml}^{-1}$ & 2.7400 & 2.2000 & 3.0000 & 3.5000 & 3.6000 & $3.01 \pm 0.26$ \\
\hline$t_{\max (\text { obs })}$ & $\mathrm{h}$ & 1.5000 & 1.5000 & 1.5000 & 1.5000 & 1.5000 & $1.50 \pm 0.00$ \\
\hline AUC & $\mu \mathrm{g} \cdot \mathrm{ml}^{-1} \cdot \mathrm{h}$ & 39.9778 & 34.385 & 47.5654 & 45.1039 & 56.4574 & $44.70 \pm 3.71$ \\
\hline AUMC & $\mu \mathrm{g} \cdot \mathrm{ml}^{-1} \cdot \mathrm{h}^{2}$ & 597.3975 & 588.0415 & 729.6347 & 678.8108 & 967.1358 & $712.20 \pm 8.92$ \\
\hline MRT & $\mathrm{h}$ & 14.9432 & 17.1017 & 15.3396 & 15.0499 & 17.1304 & $15.91 \pm 0.49$ \\
\hline$V d_{\text {area }}$ & L.kg $^{-1}$ & 1.7918 & 2.3760 & 1.5368 & 1.5769 & 1.4614 & $1.75 \pm 0.17$ \\
\hline $\mathbf{C l}_{\mathbf{B}}$ & L. $\mathrm{kg}^{-1} \cdot \mathrm{h}^{-1}$ & 0.1251 & 0.1454 & 0.1051 & 0.1108 & 0.0886 & $0.11 \pm 0.01$ \\
\hline $\mathbf{F}$ & $\%$ & 86.13 & 83.72 & 94.61 & 99.40 & 112.58 & $95.29 \pm 5.17$ \\
\hline
\end{tabular}


Table.3 Comparative pharmacokinetic parameters of moxifloxacin in calves following single intramuscular administration of moxifloxacin alone $\left(5 \mathrm{mg} \cdot \mathrm{kg}^{-1}\right.$ body weight $)$ and when pretreated with cow urine distillate ( $20 \mathrm{ml}$ per day for 7 days) orally by employing compartmental analysis

\begin{tabular}{|c|c|c|c|}
\hline \multirow{2}{*}{$\begin{array}{l}\text { Pharmacokinetic } \\
\text { parameter }\end{array}$} & \multirow[t]{2}{*}{ Unit } & \multicolumn{2}{|c|}{ Mean \pm S.E. } \\
\hline & & Moxifloxacin Alone & Moxifloxacin with CUD \\
\hline $\mathbf{K}_{\mathrm{a}}$ & $h^{-1}$ & $1.84 \pm 0.43$ & $2.22 \pm 0.28$ \\
\hline $\mathbf{t}_{1 / 2 \mathbf{K a}}$ & $\mathrm{h}$ & $0.45 \pm 0.08$ & $0.33 \pm 0.04$ \\
\hline B & $h^{-1}$ & $0.07 \pm 0.005$ & $0.07 \pm 0.002$ \\
\hline$t_{1 / 2 \beta}$ & $\mathrm{h}$ & $9.80 \pm 0.63$ & $10.53 \pm 0.35$ \\
\hline$C_{\max (\text { obs })}$ & $\mu \mathrm{g} \cdot \mathrm{ml}^{-1}$ & $3.05 \pm 0.25$ & $3.01 \pm 0.26$ \\
\hline $\mathbf{t}_{\max (0 b s)}$ & $\mathrm{h}$ & $1.70 \pm 0.12$ & $1.50 \pm 0.00$ \\
\hline AUC & $\mu \mathrm{g} \cdot \mathrm{ml}^{-1} \cdot \mathrm{h}$ & $43.30 \pm 3.99$ & $44.70 \pm 3.71$ \\
\hline AUMC & $\mu \mathrm{g} \cdot \mathrm{ml}^{-1} \cdot \mathrm{h}^{2}$ & $650.05 \pm 85.19$ & $712.20 \pm 68.92$ \\
\hline MRT & $\mathrm{h}$ & $14.87 \pm 0.91$ & $15.91 \pm 0.49$ \\
\hline Vd $\mathbf{d}_{\text {area }}$ & L.kg ${ }^{-1}$ & $1.66 \pm 0.13$ & $1.75 \pm 0.17$ \\
\hline $\mathrm{Cl}_{\mathrm{B}}$ & L.kg ${ }^{-1} \cdot \mathrm{h}^{-1}$ & $0.11 \pm 0.01$ & $0.11 \pm 0.01$ \\
\hline $\mathbf{F}$ & $\%$ & $92.62 \pm 6.86$ & $95.29 \pm 5.17$ \\
\hline
\end{tabular}

Fig.1 Semilogarithic plot of mean plasma concentration of moxifloxacin versus time data

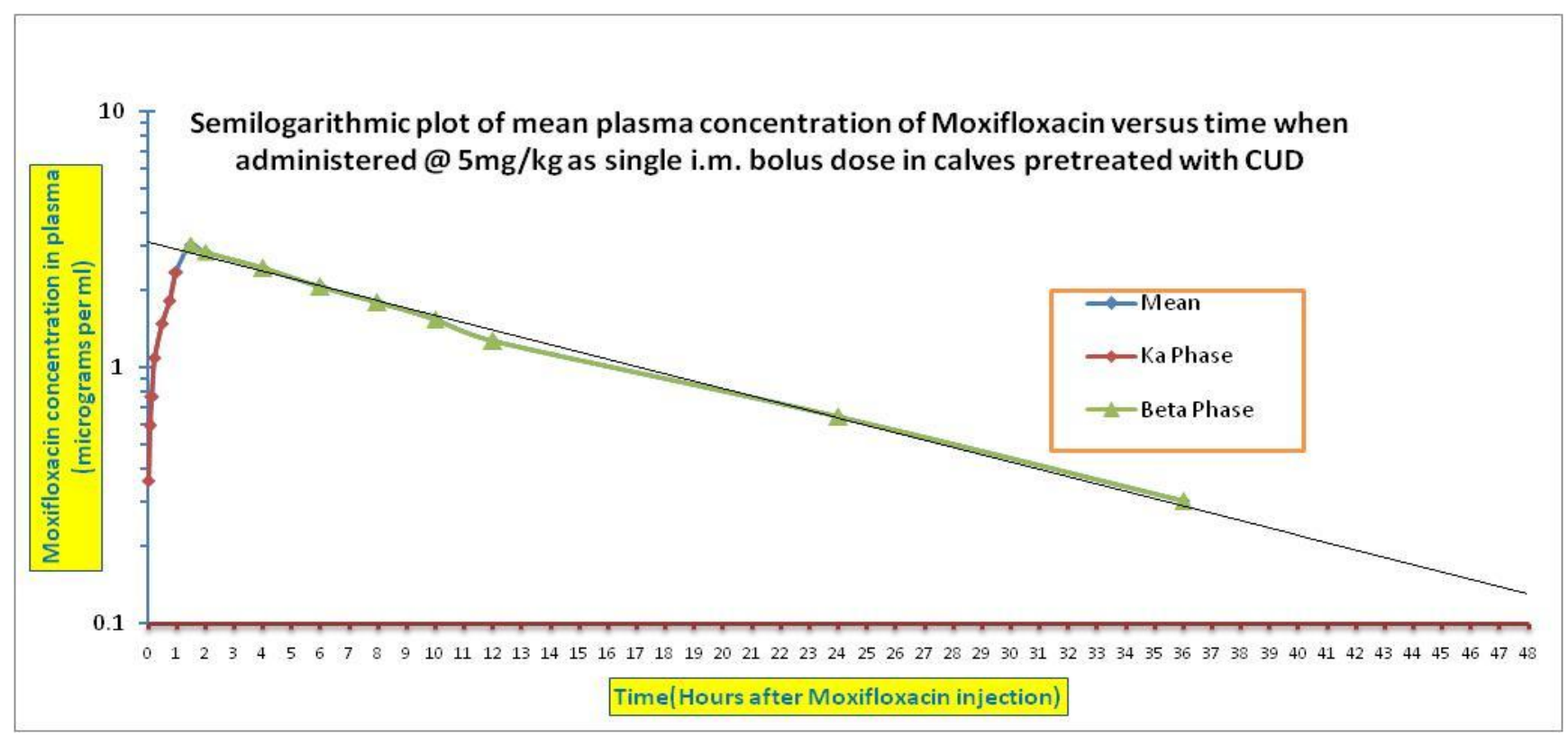

Apparent volume of distribution $\left(\mathrm{Vd}_{\text {area }}\right)$ in calves given moxifloxacin and cow urine distillate was $1.75 \pm 0.17{\mathrm{~L} . \mathrm{kg}^{-1}}^{-1}$ which is almost similar to the $\left(\mathrm{Vd}_{\text {area }}\right)$ value of $1.66 \pm$ 0.13 L.kg in calves administered with moxifloxacin alone. Differences were not statistically significant. Dama et al., (2008) found significant alteration $\left(1.11 \pm 0.08 \mathrm{~L} . \mathrm{kg}^{-}\right.$ ${ }^{1}$ to $1.37 \pm 0.11{\mathrm{~L} . \mathrm{kg}^{-1}}^{-}$) in the values of $\mathrm{Vd}_{\text {area }}$ in goats given pefloxacin alone and pretreatment with trikatu. Pavithra et al., (2009) reported significant change in the values of $\mathrm{Vd}_{\text {area }}$ in rabbits $\left(5.69 \pm 0.28 \mathrm{~L} \cdot \mathrm{kg}^{-1}\right.$ to $7.45 \pm 1.70 \quad \mathrm{~L}_{\mathrm{kg}}^{-1}$ ) following oral 
administration of norfloxacin alone and pretreatment with curcumin. In the present study total body clearance value $\left(\mathrm{Cl}_{\mathrm{B}}\right)$ in calves given moxifloxacin and cow urine distillate was $0.11 \pm 0.01 \mathrm{~L} \cdot \mathrm{kg}^{-1} \cdot \mathrm{h}^{-1}$ which was found similar to the $\left(\mathrm{Cl}_{\mathrm{B}}\right)$ value of $0.11 \pm 0.01$ L. $\mathrm{kg}^{-1} \cdot \mathrm{h}^{-1}$ in calves administered with moxifloxacin alone and the changes were found non-significant. Pavithra et al., (2009) reported the $\mathrm{Cl}_{B}$ values in rabbits when given norfloxacin alone or in curcumin pretreated calves $1.49 \pm 0.11 \mathrm{~L} \cdot \mathrm{kg}^{-1} \cdot \mathrm{h}^{-1}$ and $1.58 \pm 0.03$

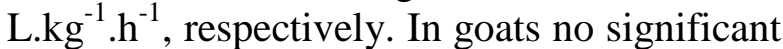
alteration $\left(0.29 \pm 0.02 \mathrm{~L}_{\mathrm{kg}} \mathrm{kg}^{-1} \cdot \mathrm{h}^{-1}\right.$ and $0.29 \pm$ $0.02 \mathrm{~L} . \mathrm{kg}^{-1} \cdot \mathrm{h}^{-1}$ ) was found when pefloxacin was given alone or pretreatment with trikatu (Dama et al., 2008).

In the present study Bioavailability $(\mathrm{F})$ in calves given moxifloxacin and cow urine distillate was $95.40 \pm 5.20$ per cent which was found higher to the $(\mathrm{F})$ value of $92.68 \pm 6.86$ per cent in calves administered with moxifloxacin alone but, the difference was not significant. Dama et al., 2008 found significant changes in bioavailability in goats administered with pefloxacin alone $(38.83 \pm$ 1.80 per cent) or in goats pretreated with trikatu $(44.18 \pm 2.90$ per cent $)$.

\section{Comparative pharmacokinetics of moxifloxacin after single intramuscular administration in calves and when pretreated with cow urine distillate orally}

Serious infections caused by microorganisms resistant to commonly used antimicrobials have become a major healthcare problem worldwide in the $21^{\text {st }}$ century. A bioenhancer is an agent capable of enhancing the bioavailability and efficacy of a drug with which it is co-administered, without any pharmacological activity of its own at the therapeutic dose used. Bioenhancers can be used to increase the efficacy of commonly used antibiotics. Cow urine distillate can act as a potential therapeutic tool to enhance the activity of antibacterial agents (Rai et al., 2013)

The pharmacokinetic parameters, derived from plasma levels of moxifloxacin after a single intramuscular dose $\left(5 \mathrm{mg} \cdot \mathrm{kg}^{-1}\right.$ body weight) alone and pretreatment with cow urine distillate $(20 \mathrm{ml}$ per day for seven days, orally), were derived using compartmental pharmacokinetic model and statistically compared; the results of which are summarized in Table 3. Statistical analysis of the results revealed that there was no significant alteration in the pharmacokinetic parameters when moxifloxacin was administered alone or given after pretreatment with cow urine distillate at the dose of $20 \mathrm{ml}$ per day for seven days orally.

The present study did not show any significant alterations in pharmacokinetic behavior of moxifloxacin administered intramuscularly in calves pretreated with cow urine distillate at the dose of $20 \mathrm{ml}$ per day for seven days orally. However, attempts should be continue to try a different dose of cow urine distillate or use of other bioenhancer in battle against the global problem of emerging antimicrobial resistance.

\section{References}

Abd el-Aty, A. M.; Goudah, A.; Shah, S. S.; Shin, H. C.; Shimoda, M. and Shim, J. H. (2008). Pharmacokinetic variables of moxifloxacin in healthy male camels following intravenous and intramuscular administration. J. Vet. Pharm. Therap., 30(6): 586-591.

Ahmed, Z.; Khan, S.S.; Khan, M.; Tanveer, A. and Lone, Z.A. (2010). Synergistic Effect of Salvadora persica Extracts, Tetracycline and Penicillin against Staphylococcus aureus. African J. Basic Appl. Sci., 2(1-2): 25-29.

Ahuja, A.; Kumar, P.; Verma, A. and Tanwar, 
R. S. (2012). Antimicrobial activities of cow urine against various bacterial strains. Int. J. Recent Adv. Pharm. Res., 2(2): 84-87.

Ajazuddin; Alexander, A.; Qureshi, A.; Kumari, L.; Vaishnav, P.; Sharma, M.; Saraf, S. and Saraf, S. (2014). Role of herbal bioactive as a potential bioavailability enhancer for Active Pharmaceutical Ingredients. Fitoterapia., 97: 1-14.

Arret, B.; Johnson, D.P. and Krishbaum, A. (1971). Outline of details for microbiological assays of antibiotics: Second revision. J. Pharm. Sci., 60(11): 1689-1694.

Baggot, J.D. (2001). Principles of drug disposition in domestic animals: The Physiological Basis of Veterinary Clinical Pharmacology. W.B. Saunders Company, Philadelphia (USA).

Cai, Y.; Wang, R.; Pei, F. and Liang, B. B. (2007). Antibacterial activity of allicin alone and in combination with $\beta$-lactams against Staphylococcus spp. and Pseudomonas aeruginosa. J. Antibiot., 60(5): 335-338.

Dama, M. S.; Varshneya, C.; Dardi, M. S. and Katoch, V. C. (2008). Effect of trikatu pretreatment on the pharmacokinetics of pefloxacin administered orally in mountain Gaddi goats. J. Vet. Sci., 9(1): 25-29.

Dhakal, P.; Acharya, A. and Joshi, V. (2016). Bioenhancing Effect of Cow Urine Distillate and Pepper Extract on Antibacterial Activity of Azadirachta indica Leaves. Int. J. Pharm. Sci. Nanotech., 9(2): 3212-3215.

Dhama, K.; Rathore, R.; Chauhan, R. S. and Tomar, S. (2005). Panchgavya (Cowpathy): an overview. Int. J. Cow Sci., 1(1): 1-15.

Fernández-Varón, E.; Villamayor, L.; Escudero, E.; Espuny, A. and Cárceles, C. M. (2006). Pharmacokinetics and milk penetration of moxifloxacin after intravenous and subcutaneous administration to lactating goats. Vet. J., 172: 302-307.
Gibaldi, M. and Perrier, D. (2007). Pharmacokinetics. $2^{\text {nd }}$ edn., Marcel Deccar lnc., New York (USA).

Goudah, A. (2008). Disposition kinetics of moxifloxacin in lactating ewes. Vet. J., 178(2): 280-285.

Janakiraman, K. and Manavalan, R. (2008). Studies on effect of piperine on oral bioavailability of ampicillin and norfloxacin. Afr. J. Trad. CAM, 5(3): 257-262.

Jarald, E.; Edwin, S.; Tiwari, V.; Garg, R. and Toppo, E. (2008). Antioxidant and antimicrobial activities of cow urine. Global J. Pharmacol., 2(2): 20-22.

Jhanwar, B. and Gupta, S. S. (2014). Biopotentiation using herbs: novel technique for poor bioavailable drugs. Int. J. PharmTech. Res., 6(2): 443-454.

Khan, A. and Srivastava, V. K. (2005). Antitoxic and bioenhancing role of kamdhenu ark (cow urine distillate) on fertilitty rate of male mice (Mus musculus) affected by cadmium chloride toxicity. Int. J. Cow Sci., 1(2): 43-46.

Khanuja S.P.S.; Kumar, S.; Shasany, A.K.; Arya, J.S.; Darokar, M.P.; Singh, M.; Sinha, P.; Awasthi, S.; Gupta, S.C.; Gupta, V.K.; Gupta, M.M.; Verma, R.K.; Agarwal, S.; Mansinghka, S.B. and Dawle, S.H. (2002). U.S. Patent No. US 6,410,059 B1. Washington, DC: U.S. Patent and Trademark Office.

Khanuja S.P.S.; Kumar, S.; Shasany, A.K.; Arya, J.S.; Darokar, M.P.; Singh, M.; Sinha, P.; Awasthi, S.; Gupta, S.C.; Gupta, V.K.; Gupta, M.M.; Verma, R.K.; Agarwal, S.; Mansinghka, S.B. and Dawle, S.H. (2005). U.S. Patent No. US 6,896,907 B2. Washington, DC: U.S. Patent and Trademark Office.

Khanuja S.P.S.; Kumar, S.; Shasany, A.K.; Arya, J.S.; Darokar, M.P.; Singh, M.; Sinha, P.; Awasthi, S.; Gupta, S.C.; Gupta, V.K.; Gupta, M.M.; Verma, R.K.; Agarwal, S.; Mansinghka, S.B. and Dawle, S.H. (2007). U.S. Patent No. US 7,235,262 B2. Washington, DC: U.S. Patent and Trademark Office. 
Moghaddam, K.; Iranshahi, M.; Yazdi, M. and Shahverdi, A. (2009). The combination effect of curcumin with different antibiotics against Staphylococcus aureus. Int. J. Green Pharm., 3(2): 141.

Mohanty, I.; Senapati, M. R.; Jena, D. and Palai, S. (2014). Diversified uses of cow urine. Int. J. Pharm. Pharm. Sci., 6(3): 2022.

Nduka, S. O.; Okonta, E. O.; Adonu, L. Z. and Okonta, J. M. (2013). The influence of ginger (Zingiber officinale) extract on the pharmacokinetic profile of pefloxacin. Int. J. Appl. Res. Natural Prod., 6(2): 1518.

Okonta, J. M.; Uboh, M. and Obonga, W. O. (2008). Herb-drug interaction: a case study of effect of ginger on the pharmacokinetic of metronidazole in rabbit. Ind. J. Pharma. Sci., 70(2): 230232.

Patel, S.; Devada, S.; Patel, H.; Patel, N.; Bhavsar, S. and Thaker, A. (2011). Influence of co-administration of piperine on pharmacokinetic profile of gatifloxacin in layer birds. Global Veterinaria, 7(5): 427-432.

Pathaniya, R. and Sharma, S.K. (2010). Pharmacokinetics and bioavailability of moxifloxacin in buffalo calves. Res. Vet. Sci., 89(1): 108-112.

Pavithra, B. H.; Prakash, N. and Jayakumar, K. (2009). Modification of pharmacokinetics of norfloxacin following oral administration of curcumin in rabbits. J. Vet. Sci., 10(4): 293-297.

Rai, J.; Randhawa, G. K. and Kaur, M. (2013). Recent advances in antibacterial drugs.
Int. J. Appl. Basic Med. Res., 3(1): 3-10.

Randhawa, G. K. and Sharma, R. (2015). Chemotherapeutic potential of cow urine: A review. J. Intercult. Ethnopharmacol, 4(2): 180-186.

Sai, K. V.; Rao, L.; Ramesh, B. and Aditya, K. (2015). Indian cow urine distillation and therapeutic uses. Mintage J. Pharm. Med. Sci., 4(1): 1-5.

Shah, C. P.; Patel, D. M.; Dhami, P. D.; Kakadia, J.; Bhavsar, D.; Vachhani, U. D.; Trivedi, M.N. and Joshi, V. J. (2011). In vitro screening of antibacterial activity of cow urine against pathogenic human bacterial strains. Int. J. Curr. Pharm. Res., 3(2): 91-92.

Shekhar, C.; Verma, S.; Sharma, M.; Singh, G.; Chahota, R. and Palial, A. (2012). Pahari cow urine: A potent bioenhancer. Indian Cow (The): Sci. Eco. J., 9(34): 14.

Shrinidhi, M. S.; Soumya, B. G.; Suchit, D. K. and ShivKumar, T. P. (2016). Antimicrobial activity of cow urine distillate; Gow-ark against 3 periodontal pathogens-an in-vitro study. International Ayurvedic Medical Journal, 4(7): 12041217.

Singh, M.; Varshneya, C.; Telang, R. S. and Srivastava, A. K. (2005). Alteration of pharmacokinetics of oxytetracycline following oral administration of Piper longum in hens. J. Vet. Sci., 6(3): 197200.

Tatiraju, D. V.; Bagade, V. B.; Karambelkar, P.J.; MJadhav, V. and Kadam, V. (2013). Natural bioenhancers: An overview. J. Pharmacogn. Phytochem, 2(3): 55-60.

\section{How to cite this article:}

Meena, M., A. Gaur, P. Sharma and Dinodia, N. 2019. Disposition Kinetics of Moxifloxacin in Calves Pretreated with Cow Urine Distillate. Int.J.Curr.Microbiol.App.Sci. 8(06): 1909-1917. doi: https://doi.org/10.20546/ijcmas.2019.806.229 